\title{
A WEB-BASED LAND INFORMATION SYSTEM, TOOL FOR ONLINE LAND ADMINISTRATION IN AKURE NIGERIA
}

\author{
*BABALOLA Sunday Oyetayo and UYI Igbinomwanhia O
}

\author{
Department of Surveying and Geoinformatics, Federal University of Technology Akure, Nigeria \\ sobabalola@futa.ng.edu
}

KEY WORDS: Web-based, Land administration, Online, Geospatial, Land information, Geographic information

\begin{abstract}
:
Access to reliable land information is a fundamental requirement for effective land administration, management, and planning and for the sustainable development of any nation. Many developing countries are faced with the absence of an adequate or coordinated land administrative system that are fit for purpose. The use of desktop geographic information system has been an effective tool for capturing, storing, analyzing, and making land information available. However, in most cases, land information is still largely inaccessible to the public where and when is needed at an instant. With the internet being an integral part of society, it is a powerful means for people to exchange and process information. The main objective of this work has been to develop a web-based LIS that facilitates users' access and retrieval of land information. In view this, QGIS was used for data processing, PostgreSQL was used for the database design while QGIS Cloud was used to expose the data as geospatial web services. Web-GIS functionality was extended with the help of OpenLayers API. The system is composed of a single database, a web mapping application and an interactive website that provides for pan, zoom, and query in GIS functionality. Adopting the system will ensure an easy flow of land information and ensures there is well-structured process of collecting, storing, and disseminating land information. However, the adoption of LADM may be possible in the nearest future.
\end{abstract}

\section{INTRODUCTION}

Land has been a major part of human existence and the effort men take to protect their rights to landed property has shaped our history. Whereby most historic events can be linked in one way or the other to the quest for more land and its associated resources. Checking the British crusades, the new world and continuing rural to urban migration, one can easily see how land and its administration affect government policies and the sustainable development of any society. This, therefore, reveals the need for stakeholders in land and environmental sectors to pay closer attention and profess efficient solutions to landrelated issues. Land administration has long been defined as the process of determining, recording, and disseminating information concerning the ownership, value, and use of land and its associated resources (UN ECE, 1996). It includes the processes of determining people's land rights, surveying, describing, and documenting these rights and providing the relevant information to support the land market. The government plays a major role in protecting the rights of people, and land administration systems provide the government with the required infrastructure to implement its land-related policies and to ensure order and transparency in the land market (Williamson, et al., 2010).

Many states in Nigeria as in most developing countries are faced with similar challenges in their land administration system. Such that the manner and tools used to administer land is still archaic and far back in technology (Ghebru \& Okumo, 2016). In an age where access to vital information can be gotten from the comfort of your bedroom once you have the required internet connection; reliable land information is still difficult to get due to the lapses in our land administrative system (Ojo, 2014). Many other aspects of society such as education, banking, transportation, etc. have shown improvements in the last decade due to the adoption of evolving technologies, however, land administration which is a very pivotal part of any society's sustainable development and economy has suffered from stagnation due to the ancient methods and workflow exhibited in most states in the country. Land administration is a broad subject that involves different processes and requires multiorganizational services ranging from adjudication (determining who really owns a landed property), surveying (accurately describing the property), to value-added taxes from the land market (Williamson, et al., 2008). Various researchers such as Chiemelu \& Eze (2014), Ojo (2014) and Babalola, et al. (2018) have contributed scholarly articles aimed at solving different aspects of Nigerian's Land Administration System in the area of registering and recording land information, however, this paper focuses on the dissemination of reliable land information via web-based GIS. Articles such as Chiemelu \& Onwumere (2013) have been written on how to administer land using desktop GIS, the public will still not have access to this land information regardless of how organized it is. Land-related information as seen in the office using desktop GIS will be more useful to the land market when there is easy access to such information through a web-based platform. Therefore, web GIS is arguably more profitable to the public.

According to Atilola (2010), the success of any land administration depends on the flow of information relating to land and property between different government agencies and between these agencies and the public. A good flow of information can, therefore, be achieved when these government agencies providing land services begin to make use of available tools such as a Land Information System (LIS) and Spatial Data Infrastructure (SDI), all of which can be made accessible to the public through the internet. Any nation serious about land reformation should certainly adopt these new methods of land administration (Didigwu \& Olakanmi, 2016; Enemark, et al., 2005). 
This study is therefore motivated by the need for surveyors to improve and expand their field of knowledge because surveyors in a modern society have moved from just the collecting of spatial data to the analysis and administration of such spatial data. As technology evolves, the practice of the cadastre surveyor in collecting and processing of spatial data also changes. Studying this evolution, it has been determined that in the future cadastral survey will become so easy that there may be no further need for a professional to be tasked in making accurate field surveys. Customers might be making field measurements themselves (Mantere, 2014). What then would the cadastre surveyor be doing? The future work of the cadastral surveyor may change to maintaining spatial database, refereeing serious cadastral problems and land management or development. Therefore, there is a need for surveyors to recognize and appreciate their responsibility in the proper land management of the nation.

\subsection{The Study Area}

Akure is a city in south-western Nigeria and is the capital of Ondo State. The town is situated in the tropic rainforest zone in Nigeria and lies between $7^{\circ} 25^{\prime}$ north of the equator and $5^{\circ} 19^{\prime}$ east of the Meridian. Akure town is situated within Akure North and Akure South Local Government Areas of Ondo state, bounded by Iju/Ita- ogbolu towns in the North, Owo LGA, and Ekiti State in the East, Idanre LGA in the South and in the West by Ifedore LGA.

Residential districts are of varying density, some area such as Arakale, Ayedun Quarters, Ijoka, and Oja-Oba consist of over 200 persons per hectare, while areas such as Ijapo Estate, Alagbaka Estate, Avenue and Idofin have between 60-100 people per hectare. As a state capital, the city is a center of commerce and administration that has attracted a large spectrum of immigrants into it. It is noted for commercial activities where buying and selling are carried out in almost every nook and cranny. (Adeoye, 2016). The map description of the study area is shown in Figureure 1.

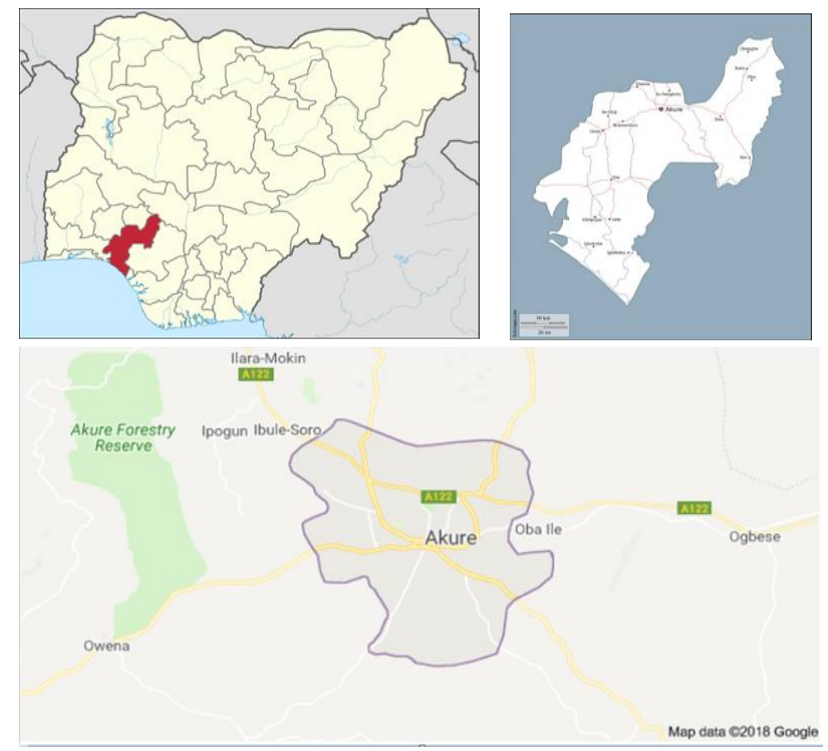

Figure 1. Map of the study area - Akure

\section{MATERIAL AND METHODS}

The following materials were used. They include dataset, hardware, and software

i .Layout plan of an estate showing land parcels in the study area

ii.Parcel attribute data such as such as land use, ownership, parcel area, parcel location, etc.

A Personal Computer (Intel Core i5 2.20 GHz, 8GB RAM memory, 1 TB Hard Disk space). QGIS, PostgreSQL and PostGIS are used for data storage. OpenLayers library makes it easy to put a dynamic map in any web page. It can display map tiles and markers loaded from any source. Web pages are designed in HTML language and JavaScript event. Notepad++ is a simple software application that provides comprehensive facilities to computer programmers for software development. it supports a wide selection of programming languages.

To meet the general objectives of the study, data acquisition comprised the use of questionnaires and GIS/LIS data capturing technique.

Two sets of questionnaires were designed for this research: The first questionnaire was designed to identify the state of stored maps and land records and how land information is retrieved in Akure, and to evaluate and determine the type of information usually sorted concerning land. The second questionnaire was used for testing or validating the project result. To determine to what extent the system provides a solution to the research problems.

LIS data capture is a technique in which the information on a map, its attributes and organizational data are collected, digitized, and organized on a target LIS system with the appropriate layers. The processes of using LIS data capturing technique for data collection are also variously referred to as data conversion, data transfer, and digitizing. In using LIS data capturing technique, two types of data were collected namely; spatial data and non-spatial data.

The first step of processing the questionnaire data involved converting the respondents' answers to numbers by means of a coding procedure. This procedure was adopted for the closedended questions while processing the open-ended questionnaire required a kind of content analysis. The information gotten from the response of the questionnaire were used to clearly define the research problem and validate the research results.

The existing layout plan was the scanned copy of a paper map used for plot allocation from the Lands and Survey Department in Akure. The plan was georeferenced and digitized in QGIS into shapefiles.

\section{Database Design}

This process involved identifying the data that went into the LIS land administration database and how it was represented. This database formed the foundation of the activities that are performed using the Land Administration System such as the Web map creation, land parcel information retrieval and spatial analysis. The attribute tables of the shapefiles were updated in QGIS, by defining more fields. The tables were populated to give more information about the digitized features. Every field was given its data and looked like the tables below. 


\begin{tabular}{|l|l|l|l|l|l|l|l|}
\hline Plot ID & $\begin{array}{l}\text { Plot } \\
\text { Num }\end{array}$ & Block & Address & Land Use & Area & $\begin{array}{l}\text { Encumb } \\
\text { rance }\end{array}$ & $\begin{array}{l}\text { C } \\
\text { of } \\
\text { O }\end{array}$ \\
\hline $\begin{array}{l}\text { AKSF000 } \\
1\end{array}$ & F & $\begin{array}{l}\text { lot 1, } \\
\text { Block Fesidential } \\
\text { Sunshine } \\
\text { Estate } \\
\text { Oda, } \\
\text { Akure } \\
\text { South } \\
\text { LGA }\end{array}$ & $\begin{array}{l}1205 . \\
526\end{array}$ & None & Yes \\
\hline
\end{tabular}

Table 1. Parcels

\begin{tabular}{|l|l|l|l|l|l|l|l|}
\hline Plot ID & $\begin{array}{l}\text { Owne } \\
\mathbf{r}\end{array}$ & $\begin{array}{l}\text { Gend } \\
\text { er }\end{array}$ & $\begin{array}{l}\text { Phone } \\
\text { Num }\end{array}$ & Email & $\begin{array}{l}\text { Next } \\
\text { of } \\
\text { Kin }\end{array}$ & Date & Payment \\
\hline $\begin{array}{l}\text { AKSF00 } \\
01\end{array}$ & $\begin{array}{l}\text { John, } \\
\text { Temito } \\
\text { pe } \\
\text { Ogbiti }\end{array}$ & Male & $\begin{array}{l}+234808 \\
6893007\end{array}$ & $\begin{array}{l}\text { uyi.osas @ } \\
\text { ymail.com }\end{array}$ & $\begin{array}{l}\text { I. } \\
\text { Osas } \\
\text { Uyi }\end{array}$ & $\begin{array}{l}03 / 03 / 1 \\
8\end{array}$ & paid \\
\hline
\end{tabular}

Table 2. Proprietor

\section{SYSTEM DEVELOPMENT}



Figure 2. Flowchart for system development

The system was designed using a three-tier architecture which contained the client layer, the application layer, and the database layer. The client layer contained web pages which were designed using HTML, CSS, JavaScript. The application layer has a web map application library and server which handles map requests by client layer. The database layer contains all shapefiles which were converted in tabular form using PostGIS extension of PostgreSQL.

Unlike desktop GIS which the application is installed to have access to its tools and functionalities, Web LIS requires web programming to add tools and functions to the web application. Web programming, also known as Web development, is the creation of dynamic Web applications. It refers to the coding involved in the system's development, which includes Web content, Web client and server scripting. The most common languages used for Web programming are XML, HTML, JavaScript, Python, and PHP. Web programming is different from just programming, which requires interdisciplinary knowledge on the application area, client and server scripting, and database technology.

Therefore, in developing the land administration system, the client, application and database layer required programming knowledge.

\subsection{System Testing and Validation}

It was the process of checking whether the result of this research met users' need. The system testing involved, testing the system online and evaluating the final product of this research to determine whether it solves the research problems or met the intended objectives. To test and validate the system, the website files, and Map application was made live by hosting it online where it could be accessed by prospective users. System validation process usually requires documented evidence. Therefore, a questionnaire was developed for prospective end users of the developed website for land administration to determine the extent to which the developed system met users' satisfaction.

\section{RESULTS AND DISCUSSION}

Despite the technological advancement readily available for daily activities, all respondents declared that land records kept in their departments were paper-based and that there was no electronic database or GIS/LIS for providing cadastral information. In view of this, land services were still disseminated manually. The internet has made access to information very fast.

However, $60 \%$ of respondents indicated an average speed in accessing land information. $20 \%$ indicated that it was slow, while the other $20 \%$ indicated that it was very slow. $80 \%$ of respondents considered it neither easy nor hard to search for land information, while $20 \%$ considered it difficult.

The result of the questionnaire, therefore, shows that the state of land administration in the study area is still archaic and follows the workflow highlighted as this research's problem.

\begin{tabular}{|c|c|c|c|c|c|c|}
\hline 1 & $\begin{array}{l}\text { How land- } \\
\text { related } \\
\text { records kept }\end{array}$ & \multicolumn{2}{|c|}{$\begin{array}{l}\text { Fully digital } \\
0 \%\end{array}$} & $\begin{array}{l}\text { Scanned } \\
10 \%\end{array}$ & $\begin{array}{l}\text { Paper } \\
90 \%\end{array}$ & \\
\hline 2 & $\begin{array}{l}\text { Available } \\
\text { electronic } \\
\text { database or } \\
\text { GIS }\end{array}$ & \multicolumn{3}{|l|}{$\begin{array}{l}\text { Yes } \\
0 \%\end{array}$} & \begin{tabular}{|l|} 
No \\
$100 \%$ \\
\end{tabular} & \\
\hline 3 & $\begin{array}{l}\text { Public access } \\
\text { to land } \\
\text { ownership } \\
\text { information }\end{array}$ & \multicolumn{2}{|c|}{$\begin{array}{l}\text { Anyone } \\
60 \%\end{array}$} & $\begin{array}{l}\text { Restricted } \\
10 \%\end{array}$ & $\begin{array}{l}\text { I don't } \\
\text { know } \\
30 \%\end{array}$ & \\
\hline 4 & $\begin{array}{l}\text { Speed in } \\
\text { accessing } \\
\text { land } \\
\text { information }\end{array}$ & $\begin{array}{l}\text { Very } \\
\text { fast } \\
0 \%\end{array}$ & $\begin{array}{l}\text { fast } \\
0 \%\end{array}$ & average & $\begin{array}{l}\text { slow } \\
20 \%\end{array}$ & $\begin{array}{l}\text { Very } \\
\text { slow } \\
20 \%\end{array}$ \\
\hline 5 & $\begin{array}{l}\text { Ease of } \\
\text { access to land } \\
\text { related } \\
\text { information }\end{array}$ & $\begin{array}{l}\text { V.Di } \\
\text { fficul } \\
t \\
0 \%\end{array}$ & $\begin{array}{l}\begin{array}{l}\text { Diffi } \\
\text { cult }\end{array} \\
20 \%\end{array}$ & $\begin{array}{l}\text { N Easy } \\
\mathrm{N} \\
\text { Difficult } \\
80 \%\end{array}$ & Easy & $\begin{array}{l}\mathrm{V} \\
\text { Easy } \\
0 \%\end{array}$ \\
\hline
\end{tabular}

Table 3. Land administration status 
The International Archives of the Photogrammetry, Remote Sensing and Spatial Information Sciences, Volume XLII-4/W16, 2019 6th International Conference on Geomatics and Geospatial Technology (GGT 2019), 1-3 October 2019, Kuala Lumpur, Malaysia



Figure 3. Pie chart showing respondents view of the speed in accessing land information

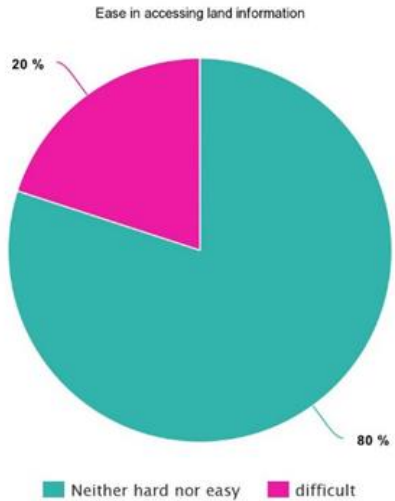

Figure 4. Pie chart showing respondents view of the ease in searching for land information

\subsection{Assessment}

In assessing the kind of information respondents usually seek concerning land, $100 \%$ of the respondents indicated they have sorted for the plot number, registration status, plot size, current owner, and encumbrance. $40 \%$ indicated to have sorted for the land use. Most respondents were challenged by the inadequate power supply in their departments and the system of filling and searching for paper land records in a dusty environment. Furthermore, respondents were challenged by the non-automatic method of land registration and title searches. Spatial databases provide a strong foundation for accessing, storing, and managing spatial data. Unlike Shapefiles it can be easily adapted into Web GIS/LIS. The type and number of attributes per feature is not limited.

\subsection{Functionalities of the web-based land administration system}

On opening the website, users get access to the welcome page. Where a brief information about the system is given and. From the welcome page, users have access to other pages on the website that offers the web map and Land Administration services. The user interface of the web application is shown in Figure $5 \& 6$ below.



Figure 5. User interface of the web-based Land Administration System (welcome page)

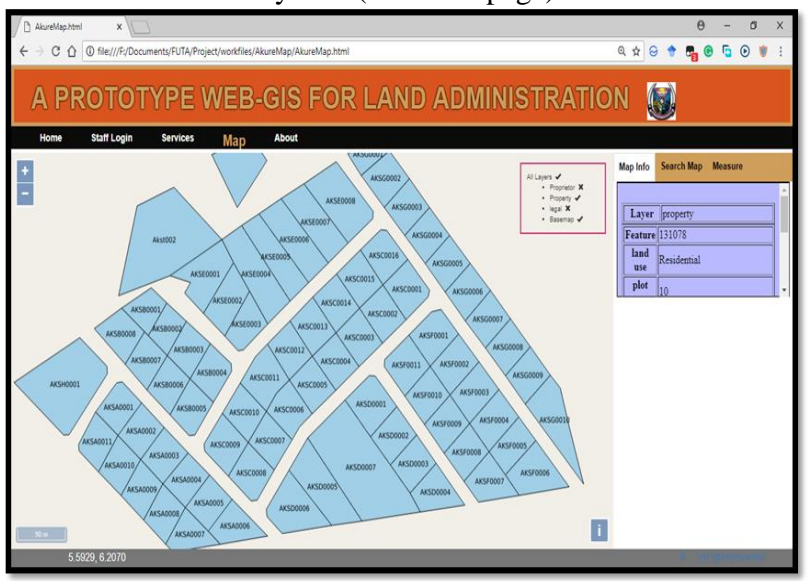

Figure 6: User interface of the web-based land administration system (web map application)

\subsection{Map Interaction and Display}

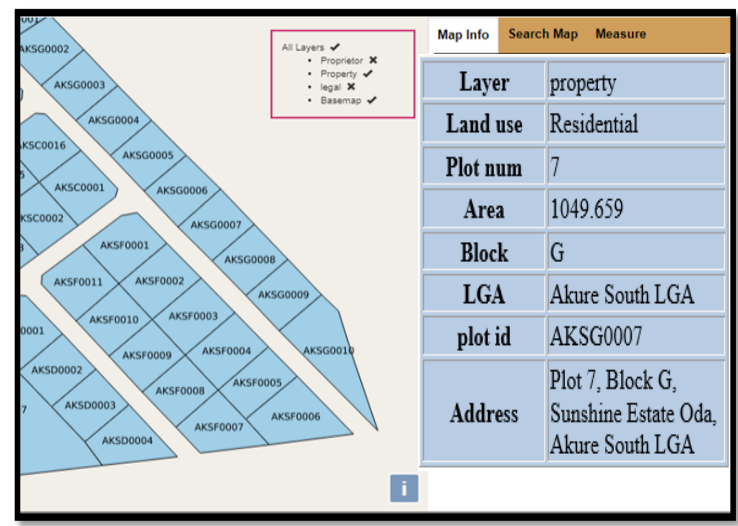

Figure 7. Get parcel information on the map

The system designed has various capabilities which are inbuilt in the system using various tools which includes:

a. Zoom in and out: used to improve the view

b. Pan: to ease navigation on the map

c. Get feature information: by clicking on a parcel, users can get information about parcels as stored in the database.

d. Toggle Layers on and off: Users can check which property information to see. Proprietor, parcel, or both 
The International Archives of the Photogrammetry, Remote Sensing and Spatial Information Sciences, Volume XLII-4/W16, 2019 6th International Conference on Geomatics and Geospatial Technology (GGT 2019), 1-3 October 2019, Kuala Lumpur, Malaysia

e. Distance and Area measurement: Users can measure distance \& area

f. View coordinates: Users can see coordinate of points as the mouse cursor move over the map

g. Search features: Users can search the map for features using either a plot ID.

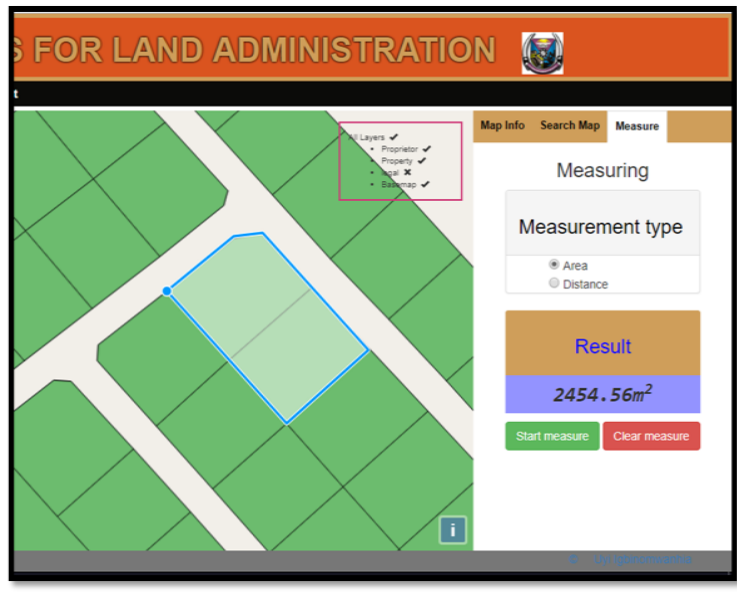

Figure 8. Measure area Tool

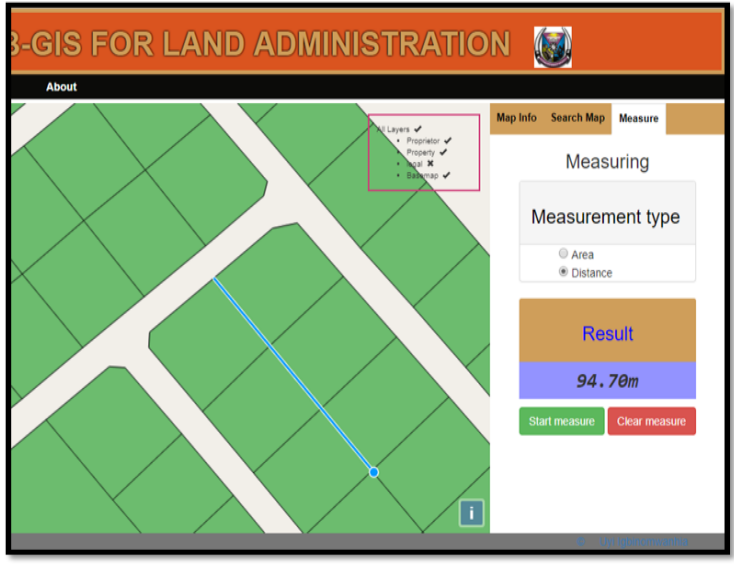

Figure 9. Measure Distance Tool



Figure 11. Staff login page

\subsection{Land services - verify title \& view parcel on the map}

Two main services are provided by the land administration system via the website to the public. Users can view the map for basic information of plots, search the map using a unique plot
ID and make title and property information request by filing a request form. Users are redirected to the web map application when choose to view or search the map. Users who choose to make a title or property information request are redirected to the request form. With the request form, users can request for the verification of a title's authenticity, check activity on a land title.

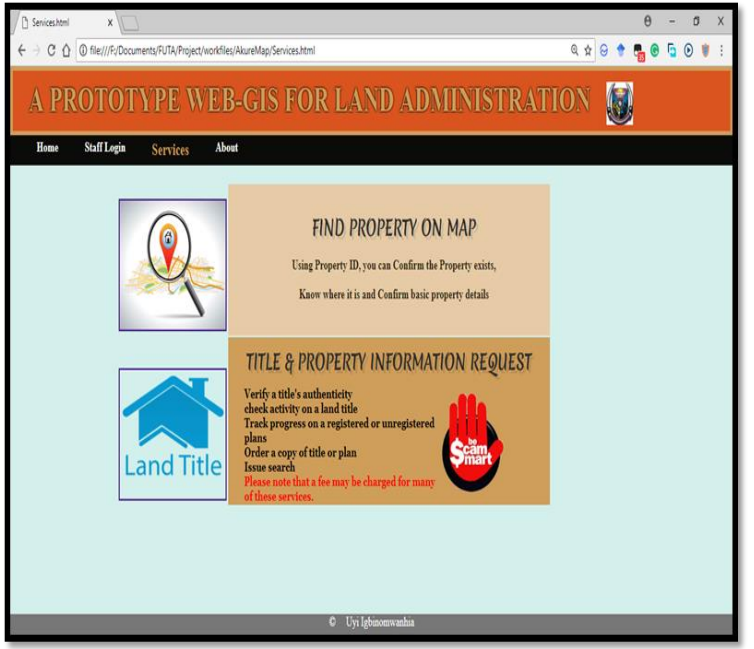

Figure 12. Services of the Land Administration System to the public

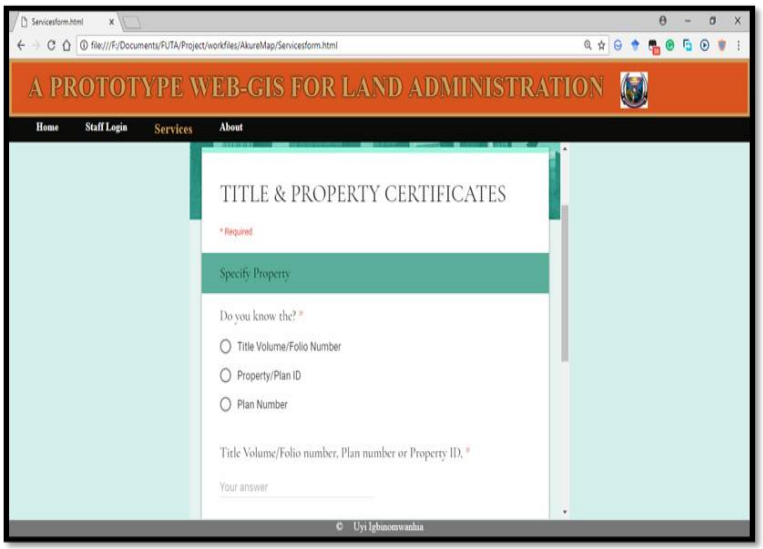

Figure 13. User interface for title and property certificates form

\begin{tabular}{|l|c|}
\hline \multicolumn{1}{|c|}{ Test } & Average Likert scale 1 - 5 \\
\hline Easy to learn & 4 \\
\hline Easy to use & 4 \\
\hline Time saving & 5 \\
\hline $\begin{array}{l}\text { Can improves job } \\
\text { performance }\end{array}$ & 4 \\
\hline Can improve productivity & 4 \\
\hline Clear Information & 5 \\
\hline Sufficient information & 2.3 \\
\hline Meets user's need & 5 \\
\hline Adds value to workflow & 5 \\
\hline Overall satisfaction & 5 \\
\hline
\end{tabular}

Table 4: System testing response and validation questionnaire result 


\section{CONCLUSION}

There is still an absence of Land Information System, maps and parcel records, there is no electronic database or GIS used in Akure's land administration. Therefore, accessibility to reliable land information can only be gotten by physically coming to the land registry to make a request. This procedure at a time when there is the availability of modern technology is very inconvenient.

The requirement for building a web-based GIS/LIS for land administration would consist of a three-tier architecture which is the database, application, and the client interface. The database would contain the spatial and attribute data of land records. The application would consist of the web map server and application programming interface. The client refers to the end users of the system who access and retrieve would land information through a web browser. Based on this research, it can therefore be concluded that the use of modern technology via web-GIS/LIS would bring ease and efficiency in land administration in Akure as provided by this work.

\section{FUTURE WORKS}

There are prospect for the adoption and application of LADM in the study area. Babalola el at (2015). Therefore, LADM will improve all activities in Rights, Restrictions and Responsibilities of the land administration in Nigeria.

\section{REFERENCES}

Adeoye, D. O., 2016. Challenges of Urban Housing Quality: Insights and Experiences of Akure, Nigeria. Procedia - Social and Behavioral Sciences, 6 January, Volume 216, pp. 260-268. Atilola, O., 2010. Land Administration Reform: Nigerian issues and prospects. Land policies in Africa, 11 April, pp. 1-16.

Babalola S O, A. Abdul Rahman, L. T. Choon, P J M Van Oosterom (2015) Possibilities of Land Administration Domain Model (Ladm) Implementation in Nigeria, ISPRS Annals of the Photogrammetry, Remote Sensing and Spatial Information Sciences, Volume II-2/W2, 2015

Babalola S O, A Abdulrahman, L. T Choon, H. Tata and A. A Tukka 2018. Web Design and Development for Land Registration: An Online Cadastral Delivery Service in Nigeria. Advanced Science Letters, pp. 3752-3757.

Chiemelu, N. E. \& Onwumere, V. O., 2013. Land Information System for Efficient Lands Administration and Revenue Generation: A Case Study of Trans-Amadi Industrial Layout, Port Harcourt, Nigeria. Journal of Information Engineering and Applications, 3(12), pp. 13-23.

Chiemelu, N. \& Eze, C., 2014. Land Administration and Management using Geographical Information System (GIS): A Case Study of Bethel Estate, Enugu State, Nigeria. Journal of Information Engineering and Applications, 4(9), pp. 57-66.

Didigwu, A. \& Olakanmi, O. M., 2016. The importance of cadastral survey information for effective land administration in Nigeria. International Journal of Environment and Pollution Research, 4(1), pp. 26-32.
Enemark, S., Williamson, I. \& Wallace, J., 2005. Building Modern Land Administration Systems in Developed Economies. Journal of Spatial Science. 50:51-68., 50(2), pp. $51-61$.

Espada, G. P., 2008. Free and Open Source Software for Land Administration Systems: A Hidden Treasure?. Stockholm, Sweden, FIGURE Working Week 2008.

Ghebru, H. \& Okumo, A., 2016. Land Administration Service Delivery and Its Challenges in Nigeria - A case study of eight states, Abuja: International Food Policy Research Institute.

Mantere, S., 2014. The Evolution of the Cadastral Surveyor. Lapland: Lapland University of Applied sciences.

Ojo, B., 2014. Evaluation of End-Users' Satisfaction on Land Title Registration Process in Akure, Nigeria. Covenant Journal of Research in the Built Environment (CJRBE), 2(2), pp. 176189.

UN ECE, 1996. Land Administration GuidelineS. Geneva: United Nations.

Williamson, I., Enemark, S., Wallace, J. \& Rajabifard, A., 2008. Understanding Land Administration Systems. Kuala Lumpur, Malaysia, s.n.

Williamson, I., Enemark, S., Wallace, J. \& Rajabifard, A., 2010. Land administration for sustainable development. Sydney, FIGURE Congress.

Revised August 2019 